\title{
Re St John, Workington
}

Carlisle Consistory Court: Tattersall Ch, 21 September 2012 Anonymous objections

In granting a faculty for the removal of a limited number of pews in the Grade II* listed church, the chancellor ignored letters filed by anonymous objectors on the basis that he did not believe that there was any legitimate reason why those who wrote them concealed their identities and in such circumstances he did not believe that it was appropriate to take them into account. [RA]

doi:10.1017/So956618X13000033

\section{Re St Alkmund, Duffield}

Court of Arches: George Dean, Bursell and Collier Chs, 1 October 2012 Alterations to listed buildings - new guidelines - hearings - 39 Articles

In allowing an appeal against the chancellor's refusal of a faculty for the relocation of a chancel screen (reported at (2012) 14 Ecc LJ 461), the Court of Arches revisited the guidelines on alterations to listed buildings adopted in Re St Luke the Evangelist, Maidstone [1995] Fam 1 (the Bishopsgate questions). The Bishopsgate questions had been subject to various criticisms. The order of the questions was illogical and unhelpful. The concept of 'necessity' led to practical difficulties and the equivalent secular regime (which the court considered in detail) did not impose a test of necessity. The questions gave rise to doubt as to the correct test to be applied where proposals would benefit, or be neutral to, the character of a listed building. Finally, they did not expressly differentiate between different grades of listing or different degrees of harm. While chancellors should not be required to apply precisely the same approach to listed buildings as the secular system, there was no justification for applying to ecclesiastical buildings a stricter test than that system applied. The court said that chancellors should be freed from the constraints of the Bishopsgate questions. In their place the court set out the following guidelines:

1. Would the proposals, if implemented, result in harm to the significance of the church as a building of special architectural or historic interest?

2. If the answer to question (1) is 'no', the ordinary presumption in faculty proceedings 'in favour of things as they stand' is applicable, and can be rebutted more or less readily, depending on the particular nature of the proposals. Questions 3, 4 and 5 do not arise. 